\title{
Papers
}

Explorations into Children's Literature

\section{Contemporary History: First Nation Australian representations in Nanberry: Black Brother White}

\author{
Sophie Stanton - The University of Canberra
}

\begin{abstract}
Representations of First Nation Australian and Torres Strait Islanders (First Nation Australians) in children's literature have gone through many changes since the first literature for children published in the late 1800 s. These representations often conformed to and perpetuated negative stereotypes that have changed with the social and political landscape. Given the degree of cultural investment in children's and young adult literature it is important to work towards a landscape in which negative stereotypes give way to representations reflecting deeper inter-cultural understandings. In this context, the analysis of contemporary texts representing First Nation Australians has an important role to play.

This paper analyses Nanberry: black brother white by Jackie French, published in 2011. Nanberry is of interest as it is a contemporary, critically-acclaimed young adult novel. The aim of this paper is to evaluate the representations of the First Nation Australian characters in the novel with reference to analytical frameworks put forward by Bradford(2001) and Lucashenko (2000/2009).

Nanberry introduces alternative narratives about the colonisation of Australia and its impacts by using artistic licence, by the adoption of First Nation Australian perspectives and also the perspectives of other historical figures of whom little to no primary evidence of their lives survives to the present day. Nanberry balances historical research with artistic licence and has an implied young, modern day readership. The intersection of these three factors, has resulted in conflict and incongruities between the characters, the plot and even the cover image. This paper argues that these incongruities and conflicts are highly problematic in relation to the representation of First Nation Australian experience.
\end{abstract}

Keywords: Representation, Aboriginalism, Nanberry, Postcolonialism, Clare Bradford, Melissa Lucashenko

\section{Introduction}

This paper analyses Nanberry: black brother white (Nanberry) by Jackie French, published in 2011 and a Children's Book Council of Australia's honour book for younger readers in 2012. The aim of this paper is to evaluate a non-indigenous Australian author's representation of First Nation Australian' characters through a post-colonial lens and with reference to 
analytical frameworks put forward by Bradford (2001) and Lucashenko (2000/2009). Although these works were published many years ago, little has been published that challenges their ideologies. Despite the length of time that has passed, the frameworks still have much to offer as a lens through which to analyse texts such as Nanberry. Their use in this paper is therefore summative rather than interrogatory. Nanberry follows the lives of several characters, some based upon real people and others entirely fictional, living in and around the English colony in Sydney Cove in 1789. The author introduces alternative First Nation Australian narratives about the colonisation of Australia and its impacts, by using artistic licence to propose First Nation Australian perspectives on the events, and by including the perspectives of historical figures of whom little to no primary evidence of their lives survives to the present day. Nanberry seeks to balance historical research and artistic licence against the reading requirements of a young, modern-day audience. This balancing act results in conflict and incongruities between the overt ideologies of presenting a positive representation of First Nation Australians and the implicit ideologies surrounding the dominance and superiority of Anglo-Australian culture. This paper argues that Nanberry does contain these incongruities and conflicts and that they are problematic in relation to the way that First Nations Australians are represented in this text.

\section{Writing and Reading Between Time and Culture}

First Nations Australian representation in Australian children's literature is a contentious issue. Australia's colonial history causes cultural, social and political tensions, and conflicts between First Nations Australians and non-indigenous Australians that manifest in various ways including, of course, in children's literature. In her book Reading Race, Bradford (2001) examined Indigenous Australian representation in Australian children's and young adult literature from a post-colonial perspective by interrogating the cultural legacy of colonisation in Australia and the ways in which it compromised children's literature in the late $20^{\text {th }}$ Century. Bradford critiqued the previously unexamined, implicit ideologies of texts that - like Nanberry - had received awards and recognition for presenting positive representations of First Nations Australian people or issues. Bradford's critiques called into question the validity of the framework that Australian society used to evaluate the 
representation of First Nations Australians in children's literature. Through textual analysis, Bradford argued that non-indigenous authors and illustrators were perpetuating, both consciously and unconsciously, colonial ideologies. She further argued that embedded ideologies within texts made assumptions about the background knowledge or culture of the reader, potentially alienating a diverse readership. Additionally, these embedded ideologies wielded significant power over both the subject and its readers, creating the possibility of real-world damage to First Nations Australians.

The post-colonial lens, as applied to literature, remains a powerful analytical tool. It provides a framework to effectively examine the influences both on and of those texts produced in societies that have experienced colonisation. As Bradford (2007)states: "[...] post colonial literary studies consider how texts inscribe the shifting relations of power and knowledge evident in colonial and post colonial societies [...]" (p. xvii). Spivak (1988) proposed that people within a colonised culture, termed subaltern, are denied access to power, just as people within the colonising culture have inherent access. As academic and intellectual observers theorise the experience of the subaltern they are reinforcing and contributing to the discourses oppress their subjects. Similarly, Chakrabarty (1992) discusses the domination of "European" history; an imagined grand narrative of history that absorbs and moulds the histories of cultures that are other, such as colonised cultures, and eliminates the possibilities for these histories to exist outside that narrative. As a product of post-colonial Australian society, Nanberry is subject to scrutiny in regard to its representations of Indigenous and non-indigenous cultures and relationships, as well as of the implicit and explicit power dynamics contained within the text. French is engaged in theorising an experience for her Aboriginal characters that conforms to a grand Eurocentric (as Chakrabarty defines it) narrative about Australian history and identity. Nanberry, as a narrative of British settlement, also directly contributes to Australian historiographical discourses, helping to reinforce contemporary Anglo-centric national identities formed on the basis of similar historical narratives. 
Nanberry, published in 2001, a decade after Reading Race, recounts the first 34 years of English colonisation of Australia from multiple perspectives which are focalised through and around the character of Nanberry, a Cadigal Aboriginal Australian child whose family dies from smallpox soon after colonisation. The colony's surgeon, who Nanberry calls 'Father White', adopts him. Father White's household also includes convict servant women, first Maria, then Rachel. Rachel bears a biological son to Father White, named Andrew. As the colony ages and grows, illness, starvation, corruption and the increasingly difficult relationships with the Eora Aboriginal Australian peoples threaten to obliterate it. Nanberry struggles to find belonging in both the English and Eora (the name given to collectively refer to several distinct language groups from the region that became Sydney, including Cadigal) cultures. He assists in translation for the colony and helps his adopted father but as he matures to adulthood, finding his identity and social standing too constrictive, he decides to become a sailor. Father White returns to England, leaving his illegitimate family, but sends for Andrew a few years later with the goal of providing him with an English gentleman's education and social standing. The epilogue depicts Andrew, now a distinguished gentleman and war hero, returning to the Sydney colony, now a fully-fledged city on the cusp of entering international levels of trade and status.

Clear examples of assumptions about the readership's cultural and historical knowledge are prevalent throughout Nanberry. The implied readership is frequently indicated to be nonindigenous Australian children with a basic knowledge of Australian history. The indications are also often exclusionary of other readerships. For example, each chapter begins with the name of the focalising character at that particular point. Below the name is a time and place reference for the reader. In the chapters focussing on English characters, the time and place is typically written in the following form:

COCKLE BAY (NOW DARLING HARBOUR), 14 APRIL 1789 (French, 2011, p.15)

In contrast, the chapters written from the perspective of the First Nation Australian protagonist, Nanberry are titled thus; 
WARRANE (SYDNEY COVE), THE TIME OF MANY FISH AND FEASTS (26 JANUARY 1788) (French, 2011, p.1)

Both ways of acknowledging time and space are "translated" in brackets for an implied readership. In the case of the English example, 'Cockle Bay' is the original European place name (overlooking any name the First Nation Australian people might have had for it), and 'Darling Harbour' is cited as the modern name, denoted by the word "now", giving a reference point for an assumed readership of contemporary children with a presumed ignorance of colonial place names. The "First Nation Australian" place and time is translated into a phrasing more recognisable by a modern Australian audience. Without the inclusion of the temporal modifier "now", though, the function of the subtitle shifts from translating across time, to translating between cultures. This carries with it the implication that First Nation Australian knowledge is lesser than and in greater need of translation to AngloAustralian knowledge, and that Nanberry's way of telling time and place is not sufficiently sophisticated, nor specifically detailed to stand alone without translation. Additionally, removing the temporal modifier relegates representation of First Nation Australian culture in the novel to a distant historical place, thereby excluding an implicit, modern First Nations Australian readership. As the narrative progresses and Nanberry is indoctrinated and assimilated into English culture, the structure of the time and place references at the beginning of his chapters also shifts:

SYDNEY HARBOUR; KAYEEMY (NOW MANLY COVE), 1 AUGUST 1789 (French, 2011, p.82)

The new time and place format is thus stylistically aligned with those at the beginning of the English characters', signifying Nanberry's assimilation into English culture. He has acquired the same method of knowing time and place as the colonisers, while simultaneously abandoning or forgetting his Aboriginal Australian knowledge. 
Further privileging of non-indigenous knowledge occurs throughout the text of the novel. The First Nation Australian and English characters are constantly placed in opposition or, at least, in a position to be directly compared to each other; 'The big canoes floated straight towards them as though the warriors were buzzing bees who had no sting.' (French, 2011, p.3) In this quote, taken from the opening chapter of the narrative, Nanberry is watching the "big canoes", the English ships of the First Fleet, arriving to colonise Australia. The image emphasises the might of the colonisers and the helplessness of the Eora people. The warriors from Nanberry's language group, who are the most powerful people in Nanberry's community, are described as "bees who had no sting" (French, 2011, p.3) and are thus emasculated and deprived of agency in the mere presence of the colonisers. Later, this disempowering image is tempered somewhat by descriptions of successful resistance of colonisation by Eora peoples. This is one of many power struggles presented in the novel, both physically and metaphorically violent. In this example, it is not just Indigenous knowledge that is represented as inferior, but physical strength and technology as well, reenforcing through subtext the stereotypical image of a savage and ignorant native culture. As with this example, in each case the implicit meanings are incongruent with the explicit attempts of the novel to foreground a First Nation Australian perspective.

This example is also one of many, early in the novel, positioning readers to sympathise with the colonised while, simultaneously, aligning themselves with the colonisers. This position inserts a paternalistic aspect into the text. There is an expectation that the reader will have the knowledge to understand that in the context of the narrative the "big canoes" are ships and to recognise and identify with the culture that produced them. The implied readership is therefore non-indigenous and is encouraged, at least at the beginning of the text, to view Nanberry and the other First Nation Australian characters as not only very different, but in every way as being 'other'. In this case, as with the time and place descriptions, both coloniser knowledges and the knowledge of the assumed reader are placed in a privileged position above that of Nanberry, and by extension above the other First Nation Australian peoples in the novel. 


\section{Aboriginalism}

The positioning of the reader and privileging of non-indigenous knowledge defines Nanberry as an Aboriginalist text. Derived from Said's (2003) concept of Orientalism, "Aboriginalism" is the term used to describe texts written about and on behalf of First Nation Australian people for a predominantly non-Indigenous readership (Hodge \& Mishra, 1991). Bradford (2001) argues that descriptions which perpetuate the colonial idea of savage, backwards natives, even when the primary motivation is irony or historical accuracy, is unacceptable. The use of these colonial ideas in critically lauded novels further entrenches racist ideologies in society. Further, the prominence and recognition of these novels asserts the primacy of the knowledge they contain and authority to their representations of First Nation Australian peoples and culture;

To look closely at the discourses which inform these texts is to recognise how the warm glow of Aboriginalism conceals its appropriating and controlling strategies. [...] In Australian children's literature, the dynamics of Aboriginalism, knowledge and power operate by positioning the child readers to assent to the versions of Aboriginality proposed by the knowledgeable and sympathetic experts, who speak about and for Aborigines. (Bradford, 2001, p. 110)

Aboriginalist texts both perpetuate the racism they try to combat and patronise the culture they seek to help. Their influence in this regard is insidiously cloaked in explicit overtures of advocacy and sympathy for their subjects. While acknowledging the intentions and, to some extent, the success of such literature in bringing positive attention to First Nation Australian peoples - where they might otherwise be ignored or persecuted - Bradford implies that the honourable reputation many Aboriginalist authors have attained within Australian society is undeserved because of the damaging misrepresentation of their subjects. Bradford's position is reflected in Lucashenko's (2000/2009) argument that, although sympathetic representations of First Nation Australian peoples are well-intentioned, they are rarely in the interest of First Nation Australian peoples. 
Most information that white Australians hold about us is from non-Aboriginal sources. Most of this information is grossly misleading and much of it is prejudiced. I suggest you consider if and, crucially, you want to add yet another non-Aboriginal portrayal to a long and undistinguished list. (Lucashenko, 2009, p. 7)

Similarly, Bradford's main argument against Aboriginalist representation is that sympathetic notions, such as writing for First Nation Australian peoples, both assumes that they are incapable of writing for themselves and robs them of the capacity to do so by using hegemonic power to take over a space, both in the literary world and in wider society, that would otherwise be filled by authentic First Nation Australian perspectives.

Nanberry is problematic in terms of Aboriginalism for two reasons. The first Aboriginalist aspect of Nanberry is apparent in the light of Lucashenko's suggestion that, if nonindigenous authors must write about First Nation Australian people, they should not appropriate the voice of an Indigenous person.

The position of the informed and self-conscious observer is a position that doesn't harm us greatly as the viewed, or you, as the viewer. It is the diametric opposite of trying to write as a pseudo-Aboriginal person. (Lucashenko, 2009, p.7)

Lucashenko argues that non-indigenous writers should take the role of a non-indigenous observer in order to avoid imposing incorrect, non-indigenous ideas onto First Nation Australian peoples and cultures. The point of view taken in Nanberry is problematic in light of Lucashenko's concerns. Nanberry is told in third person omniscient point of view, but with each chapter shifting its narratorial focus between characters. While not as subjective as a first-person point of view, the perspective in each chapter is limited to the experiences, observations and thoughts of the focalising character. Nanberry, as the eponymous protagonist, has many chapters focalised through his experience. While not purporting - as would be the case with first-person point of view - to inhabit a 'pseudo-Aboriginal person', 
the focalisation technique means that the point of view is far from 'self-conscious observer'. The novel therefore stands in contradiction of Lucashenko's assertion and, in effect, places French in the Aboriginalist position of being a non-indigenous person, speaking with authority from what is effectively a subjective First Nation Australian perspective. The second Aboriginalist aspect of Nanberry is the sympathetic and romantic representations of Nanberry and his relationships with the colonists. The focus of the novel begins with First Nation Australian and non-indigenous lives portrayed as being in binary opposition to one another. The opposition is then broken down by the assimilation of the colonised into the colonising culture. This is represented as a positive and even desirable outcome. Even before the book is opened, the cover design, as viewed on Harper Collins' website (Harper Collins, n.d.), is positioning the reader to consider the First Nation Australian as vulnerable and weak and the non-indigenous Australian as powerful and sophisticated. The tagline, "Two brothers - one black, one white [...]", and the subtitle "Black Brother White" immediately and overtly places the two cultures into opposition. The subtitle in particular, splashed in white across an Aboriginal child's body, highlights this opposition as a major theme in the text. The opposition between Indigenous and non-indigenous becomes more problematic as the narrative progresses, as First Nation Australian culture is assimilated into colonial English culture. The child on the cover presents a vulnerable image. He is wet, bedraggled and covered with goose bumps. His hand to his mouth and his expression suggests anxiety, which combines with his vulnerability and youth to create the impression of a character who cannot survive without assistance and protection. This image of vulnerability is not necessarily representative of Nanberry as a character. While he does have moments of vulnerability and is in need of care when he contracts smallpox at the beginning of the novel, in many other ways he is a strong character who takes on responsibility for himself and others in ways that belie the cover image. The decision to visually represent Nanberry in this way evokes sympathy and a certain amount of goodwill towards the people who would care for him, but ignores the strength and agency that Nanberry shows in the narrative. 
In contrast, the white men in the background are adults and their bearing and clothing evoke power, sophistication and control. They have houses, fences, docks and ships, while the child has no shelter or possessions. The photographic depiction of the boy, as well as his size and position in the foreground, emphasises both his importance within the novel and also to history. The different styles of image, however, also suggest the distance between Nanberry's reality and the reality of the drawn or painted white men in the background; There is a sense that they are irreconcilable, that one must subsume or eliminate the other. Nanberry's ability to live "between" cultures is derived from elements of his character that are portrayed as special or exceptional when compared to other Aboriginal characters. The doctor of the new colony, Surgeon White, raises Nanberry when his family dies of smallpox. It is Nanberry's struggle to find identity between cultures that is the root of many of the tensions between First Nation Australian and non-indigenous cultures presented in the novel.

The boy stared at him, obviously trying to work out what his words meant. Ha! Thought the Surgeon. The boy was no fool. Even Arabanoo hadn't learnt as much this quickly. (French, 2011, p.44)

This is another of the many references to Nanberry as an 'exceptional other', who can bridge the gap between Anglo and First Nation Australian cultures in a way that the rest of his culture cannot. As the narrative progresses Nanberry takes on more "English" ways of acting and speaking, resulting in his being shunned by people of both cultures and creating an identity crisis.

Nanberry resolves this crisis by accepting both cultures and living alternately in one then the other. Because of this hybridity he has more capability to make this decision than someone from one culture alone. 
He was Cadigal and English! He could see more in this land than any Englishman ever could, the way he had found birds for Father White. He could travel on giant ships and see the world as no other Cadigal could do. (French, 2011. p.215)

Nanberry's narrative from this point on is portrayed as "happily ever after", partly because of his acceptance of both cultures but mostly because his status as exceptional allows him to assimilate into the dominant, colonising culture. This is contrasted with the other Eora characters who either express outward distain towards, and actively resist, English culture, or who simply aren't portrayed as being exceptional enough to assimilate properly. Arabanoo is kidnapped and held captive until his death from small pox, Balloonderry violently resists the English and is condemned to death, but dies painfully of disease. Booroong is taken into servitude and is described as unhappy in that position. Bennelong is captured, ridiculed and becomes an alcoholic. And hundreds of unnamed Eora characters also die from smallpox throughout the course of the novel. Their tragic stories are generally conveyed with a romantic sympathy, such as that exemplified in the passage below.

If only he had laudanum left, to ease the old man's suffering. And Arabanoo had borne it all with serenity with which he'd faced his captivity, the gentleness with which he treated all he met, from the most ragged convict child to the Governor. [...]

Arabanoo turned his head so he could see Nanberry. He pulled at the Surgeon's hand. His eyes pleaded.

The Surgeon realised what Arabanoo was asking.

'I'll look after the lad. I promise.' He meant it. They had taken so much from this man already: his freedom, his people, and now his life. The least he could do was to make sure the child was safe.

Arabanoo muttered in his fever. The Surgeon gripped his hand again, and the old man grew quiet.

No man should die like this, away from his people. (French, 2011, pp. 48-9) 
Arabanoo is presented here as the epitome of the 'noble savage'; dignified, selfless and placid in the face of his pain and mortality. Aboriginal Australian people in the novel seemed doomed to death and misery as punishment for transgressing the social expectations (James, 2009) of assimilation. Only Nanberry, with his exceptional ability to assimilate, leads a fulfilling and happy life. Nanberry does die during the course of the novel. His death is related in the epilogue from Andrew's perspective as an adult returning to the colony and his family, of which he regards Nanberry as being an intrinsic part.

\section{Old or New Australians?}

Andrew and Nanberry's relationship has a direct bearing on how Nanberry is represented especially in death. Nanberry takes responsibility for Andrew's education in Aboriginal Australian knowledge while Father White takes responsibility for his English education. Nanberry arranges for Andrew to meet and be taught by Aboriginal Australian boy of about the same age.

'You were born in this land, Andrew. Your body is made of its earth, just as mine is. I remember that when I am travelling. You must remember it too.'

Andrew nodded. It didn't make sense but so much adults said didn't make sense. 'Garudi learns things from his clan. Now you are his friend he will teach them to you.'

Andrew looked at the boy suspiciously. He was naked, like most of the savages. His hair was tangled. His feet looked as though they had never worn boots at all. How could a boy like this teach him anything?

The boy looked back, equally suspicious.

'Come,' said Nanberry. He spoke more words to Garudi, a long patter of words that sounded like o'possums' grunts, not real words at all. (French, 2011, p. 241)

As seen through the perspective of a colonial boy of about five years old, the Aboriginal Australian boy is a 'savage', animalistic, uncivilised and without language. Nanberry is exempted from this imagery because of his assimilation; his grasp of English language, 
culture and clothing makes him, more advanced than other First Nation Australians. Andrew's relationship with Garudi is presented to the reader as an equal cultural exchange as described within the text by Nanberry. However, the exchange is, in fact, far more onesided, with Andrew neglecting Nanberry's wishes that he should teach Garudi English. Their time is spent hunting, fishing and swimming. They communicate non-verbally through movement, emotion and dance.

Garudi pointed at the spears and did a little dance of joy. Andrew joined him, dancing too, holding the spears up above his head. It was as though they danced with the waves and the spray, like the fish swimming in the cool green water. There were many ways to talk to each other when you didn't have words, many ways to show that you were happy. (French, 2011, p. 247)

Their relationship is highly romanticised by the idyllic imagery, setting and activities that they engage in together. However, while Andrew can return to the colony and eventually England, and therefore civilisation, Garudi is never invited into that space. He is without a voice in the text and exists only within Andrew's romanticised experience of the Australian landscape and Aboriginal Australian knowledge. The epilogue reinforces Garudi as a romanticised noble savage, conforming to and perpetuating early colonial descriptions of First Nations Australians (Heiss, 2002).

Suddenly he was a boy again. These were the rocks where he'd speared fish with Garudi. It hadn't been a dream, after all. The waves were the same, slapping against the rocks, the white spray.

But no Garudi. No black limbs outlined against the startling blue of the sky. How could he have forgotten this sky?

What had become of Garudi? Is there even, he wondered, any way to find out? (French, 2011, pp. 268-9) 
This is the last mention of Garudi in the main text. His present and future are a mystery without the possibility of solution. As such, he is relegated to Andrew's past, childhood memories and dream-state and his noble savage status is left unchallenged. For Andrew, however, this is return to his homeland. He feels a visceral connection with the place despite spending most of his life as an English gentleman.

The end of Nanberry's narrative is shown to the reader in retrospect through Andrew's focalised perspective. Andrew's perspective, in general, introduces imagery and ideology that conforms to Aboriginalist images of the "noble savage" as well as raising issues of authentic identity. Nanberry and Andrew are brothers, considered sons of Father White, albeit through illegitimacy and adoption.

Nanberry had been in his forties when he died, old age for a sailor. It might have been from scurvy or influenza [...]. That whole part of his past was locked to him now.

Andrew hoped Nanberry hadn't died alone.

He looked back at the grave among the trees and flowers, at the sparkling river and the gleam of cliffs. No, His brother had died with those he loved around him and in the land he loved as well.

Suddenly another word from the past came back to him. 'Babana,' he whispered. 'Brother. Goodbye, babana. Thank you for teaching me to see the land around me. It's stood me in good stead. Rest in peace.' (French, 2011, p. 273)

By the end of Nanberry, the first Australian-born colonists, as represented by Andrew, have become the new Australians while the First Nations Australians have either died or faded into the past. The essential and authentic aspects of Australian identity are transferred to the colonists as the new Australians. Connection to country and language are now within their purview alone. In Nanberry there is no future for authentic First Nations Australian peoples or culture. In this, the novel reflects Ashcroft's 2001 observation (in Bradford, Mallan, Stephens, \& McCallum, 2008) that: 
'Historicism fixes the indigenous subject at a static moment in the past, a prehistory located under the sign of the primitive; a primal innocence or barbarity. This is the static historical moment from which History, the record of civilisation begins'. (p.61)

This is especially clear in light of Andrew's reflections on his childhood adventures with Garudi. The conclusion of Nanberry not only perpetuates the colonial narrative of First Nation Australian cultures as a primitive and historical, denying their resilience and modernity but also reinforces the authentic Australian identity of the colonisers.

\section{The Paratext}

In most novels, the end of the narrative is also where the reader is signalled to disengage from the text. However, Nanberry includes an expansive 'Author's Notes' section. These notes alone take up almost ten percent of the text, and attempt to explain and justify French's creative decisions regarding the research and writing of the novel. In the case of First Nation Australian representation discourses, analysis of paratexts can be significant. As explained by O'Conor (2010):

The importance of the paratext lies in the framing strategy it offers readers as a means to interpret the book. Paratextual contributions may overtly or subtly promote authorial credibility. (p. 12)

The effect of French's author's notes is to reveal the methodologies that underpin many of the problematic, implicit ideologies of the novel. Research and writing methods, while often not considered relevant to studies of literature, become relevant when discussing First Nation Australian representation. Lucashenko (2000/2009) outlines some of the practical issues that emerge when non-indigenous writers represent First Nation Australian people and culture in their work. She explains that First Nation Australian Law is closely intertwined 
with every aspect of the diverse cultures, and that misrepresentation of First Nation Australian Law has significant and harmful impacts on First Nation Australian society.

My elder and I speak about the way an intricately interwoven Law is the bedrock of Aboriginal culture, how our Law may be trashed by a particular kind of nonAboriginal thinking. How non-Aboriginal stories have the power to distort our lives. About the fatuous Aboriginal stereotypes which inhabit the minds of many Australians and are reproduced in book after book, story after story, policy after policy. (Lucashenko, 2009, p.5)

She emphasises the fact that the source of much non-indigenous knowledge of First Nation Australian culture is drawn from non-indigenous assumptions and has generally had very little authentic First Nation Australian influence or interrogation, making the chances of creating something harmful far more likely, even if the artist undertakes research as part of the creative process.

French's author's notes are largely concerned with outlining and defending the strength of the evidence she put together - evidence drawn almost entirely from English records from the era - and with outlining the unreliability, ambiguity and scarcity of them. French acknowledges that her choices of what information to include and what to discard may not comprise a correct interpretation. She also reflects upon the difficulties posed by the passage of time, stating:

It is impossible to truly understand either the English or Eora cultures of the 1780 s and 90 s. We are simply too far away to understand people whose reasons for doing things and customs were so different from ours. (French, 2011, p.278)

This reflection becomes problematic when read in the context of the subsequent notes about the historical figure of Nanberry and his representation within the novel. Having succinctly outlined the bare facts and evidence she used for the other characters, French 
includes a couple of suggestions of personal feelings that Nanberry might have had, but provides no empirical or historical evidence for the conclusions she has drawn in this regard. Phrases such as:

It must have been a terrifying time for the small boy; no wonder that he turned to his protector and decided to 'become English'. Perhaps nine out of ten of the First Nation Australian people around Sydney Harbour died. All, or at least most, of the others fled inland, away from the disease - the only thing they could do in the face of such a savage death rate. Nanberry must have felt his old world had died too. (French, 2011, p.286, [my italics])

This admission of the degree to which the characterisation of Nanberry rests upon French making assumptions about the character's feelings, motivations and state of mind stands in direct contradiction to French's earlier statement as to the impossibility of truly understanding his culture or perspective. That similar assumptions haven't been made about the other (European) historical figures in the author's notes is a problem made even more conspicuous by French's comments that there is almost no evidence remaining of Nanberry's life and certainly nothing to suggest his personal thoughts and feelings. This 'fictionalising' of Nanberry as an historical character is taken further than it is with the other characters, to the point where it extends into author's notes section of the book, a place traditionally regarded as being more factual and authoritative than the main narrative. Of particular note, is French's research into the languages of the Eora peoples. The Eora words used in the text are mostly nouns scattered throughout Nanberry's chapters and used in dialogue between First Nation Australian characters to denote their Aboriginality and difference from the English characters.

The 'Aboriginal' words l've used in this book were those written down by English people from 1788 to 1820 . This means they are almost certainly not very accurate. But as with so many of the incidents in this book, I chose to rely on the 
written records of the time, balanced with what I know of Indigenous tradition and history. (French, 2011, p. 295)

French cites the lack of First Nation Australian sources from the colonial period as the reason for using solely non-indigenous sources for Eora words. i The citation above is evidence that the research methodology which underpins Nanberry is founded on a principal - of privileging written primary sources - that inherently silences First Nation Australian voices and privileges colonial ones. The extent and source of French's knowledge of 'Indigenous tradition and history' is not expanded upon and so there is no basis for the reader to evaluate the extent to which French's representation 'has felt the direct influence of an Aboriginal mind' (Lucashenko, 2009, p.5). Additionally, this section of the paratext explains and supports French's authority over Eora languages (O'Conor, 2010).

There is a contradiction between French's strict preference for primary written sources for Eora languages and her research practices in other areas. She acknowledges the gaps in the historical record, lists contemporary reference texts and uses her authority as a contemporary artist to interpret and flesh out events and characters. She acknowledges the devastating effect that Colonisation had upon First Nation Australian languages and cultures:

But when the nations were destroyed by disease and occupation of their lands many of the oral histories died with their custodians. (p. 295)

The decision to use solely sources from the colonisers to re-create First Nation Australian language is therefore a problematic extension of the oppression and silencing of Indigenous languages.

\section{Conclusion}

With the inclusion of her author's notes French has chosen to insert herself, explicitly and implicitly into her novel. Her decisions regarding research, inclusion and exclusion of information and the extent to which she relied upon 'artistic licence' as she fleshed out the 
historical evidence suggest a level of awareness of with tensions that are inescapable when dealing with fictional representation of First Nation Australian experience. Evidence of this is littered throughout the text, most overtly in the author's notes. Despite the explicit purpose of the text being to tell a positive story about a First Nation Australian character, the implicit messages concerning Indigenous representation are often problematic, and hark back to Aboriginalist by-products of disempowerment and speaking for First Nation Australian people. Bradford's research was published sixteen years ago and yet Nanberry is evidence that Aboriginalist texts are still entering the public arena. Given the prominence of French and this novel, this book is commonly found in school libraries across Australia, creating the potential for problematic, embedded ideologies in relation to First Nation Australian representations to remain prevalent and unchallenged. The analytical frameworks offered by Critical Literacy in regard to pedagogy and connectedness, while not within the scope of this paper, would provide further investigation into the real-world effects of these potentially damaging ideologies. It is for this reason that Nanberry: Black Brother White and contemporary texts like it need to be examined and the results disseminated among academics, teachers and readers.

\section{Notes}

i. For the purposes of this paper I will use the terms "First Nations Australians" or "Indigenous Australians" to encompass all Australian Aboriginal and Torres Strait Islander peoples and cultures where there is a need to generalize. I will use "Aboriginal Australians" to refer to mainland First Nation Australian peoples as distinct from First Nation Australians from the Torres Strait Islands. I will use the term "non-indigenous" to refer to people of Anglo-Australian or other cultural backgrounds. I also preface this paper by acknowledging that I am a non-indigenous Australian.

ii. Contemporary sources for Eora languages are publicly accessible in print: Troy, Jakelin. 1994. The Sydney Language. Canberra: Australian Dictionaries Projects, AIATSIS. Or online through websites such as http://dharug.dalang.com.au/language/dictionary

\section{References}

Bradford, C. (2001). Reading Race: Aboriginality in Australian children's literature. Melbourne: Melbourne University Press. 
Bradford, C. (2007). Unsettling Narratives: postcolonian readings of children's literature. Canada: Wilfrid Laurier University Press.

Bradford, C., Mallan, K., Stephens, J., \& McCallum, R. (2008). New World Orders in Contemporary Children's Literature: Utopian Transformations. New York: Palgrave Macmillan.

Chakrabarty, D. (1992). Postcoloniality and the Artifice of History: Who Speaks for "Indian" Pasts? Representations, 37, 1-26.

French, J. (2011). Nanberry: Black Brother White. Sydney: HarperCollins Publishers Australia. Harper Collins. (n.d.). Nanberry: Black Brother White. Retrieved September 26, 2017, from http://www.harpercollins.com.au

Heiss, A. M. (2002). Writing about indigenous Australia: some issues to consider and protocols to follow: a discussion paper. Southerly, 62(2), 197.

Hodge, B., \& Mishra, V. (1991). Dark Side of the Dream (1st ed.). North Sydney: Allen \& Unwin Pty Ltd. James, K. (2009). "There”s a black boy dead and a migloo holding a gun': Death, Aboriginality and Hisory in Australian Adolescent Literature. Papers: Explorations into Children's Literature, 19(1), 5-16. Lucashenko, M. (2009). Muwi muwi-nyhin, binung goonj: boastful talk and broken ears. Writing Queensland, (186), 5-7. (Reprinted from QWC News Magazine, 85, 2000, 8-10)

O'Conor. (2010). From Colonial Superstition to the Hairyman: Aboriginality and the politics of race. Papers: Explorations into Children's Literature, 20(2), 11-22.

Said, E. W. (2003). Orientalism (3rd ed.). London: Penguin Books.

Spivak, G. C. (1988). Can the Subaltern Speak? In C. Nelson \& L. Grossberg (Eds.), Marxism and the Interpretation of Culture (pp. 271-313). Urbana Il.: University of Illinois Press.

\section{Biographical Note}

Sophie Stanton is a Phd Candidate at the University of Canberra. Her research encompasses Aboriginal and Torres Strait Islander (First Nation Australian) representations in contemporary, Australian young adult literature and writing methodology. She is currently working on articles related to the methods and ethics of writing between cultures, the representation of First Nation Australian voices and the role of paratextual elements in First Nation Australian Representation. 